\title{
The Interiorization of COVID-19 in the cities of Pernambuco State, Northeast of Brazil
}

Rosalva Raimundo da Silva 1

iD https://orcid.org/0000-0003-2096-9815

Geyssyka Morganna Soares Guilhermino 2

iD https://orcid.org/0000-0002-0563-0963

Barnabé Lucas de Oliveira Neto 3

https://orcid.org/0000-0002-1295-5977

José Bonifácio de Lira Neto 4

https://orcid.org/0000-0002-9819-9438

\footnotetext{
Centro de Pesquisas Aggeu Magalhães. Fundação Oswaldo Cruz. Av. Prof. Moraes Rego, s.n. Cidade Universitária. Recife, PE, Brasil. E-mail: rosalva jupi@hotmail.com 2 Faculdade de Ciências Médicas. Universidade de Pernambuco. Recife, PE, Brasil.

3 Universidade Federal da Paraíba. João Pessoa, PB, Brasil.

4 Associação Municipalista de Pernambuco (Amupe). Recife, PE, Brasil
}

\begin{abstract}
Objectives: to analyze how the disseminationof COVID-19 occurred in the cities of Pernambuco State, Northeast in Brazil.

Methods: descriptive, exploratory and quantitative study whose units of analysis were the 184 cities and Fernando de Noronha Archipelago which constitutes the state of Pernambuco. Geoprocessing techniques used QGis 3.14.16 and were presented in figures.

Results: the first city to register a case of COVID-19 was Recife, in 129 days there were already confirmed cases of the disease in all the cities in the state and including Fernando de Noronha Archipelago. Only 117 cities informed the patients'sexin public reports since the first case and only 88 cities mentioned the patients' age.

Conclusion: there was a fast spread of COVID-19 in the state of Pernambuco, showing the inability of the Health Surveillance services to control the transmission, especially in smalltowns.
\end{abstract}

Key words Betacoronavirus, COVID-19, Epidemiological monitoring, Dissemination of information, Health planninge

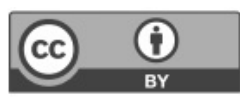




\section{Introduction}

COVID-19 (Coronavirus Disease 2019) is a highly transmissible infectious disease caused by the new coronavirus (SARS-CoV-2) (Severe Acute Respiratory Syndrome-Coronavirus-2). It emerged in December 2019 in the People's Republic of China, in the city of Wuhan, through a pneumonia outbreak, with an unknown etiology at the time, initially it started in a seafood and animal market, and with its rapid spread became an epidemic. ${ }^{1-4}$

On January 30, 2020, COVID-19 case event was considered a Public Health Emergency of International Concern (PHEIC). 5,6 In South America, the first country to officially register a confirmed case for COVID-19 was Brazil, on February 26, 2020 in the city of São Paulo. It was a 61-year-old man with a recent history of traveling to Italy, but analysis caried out by researchers at the Oswaldo Cruz Foundation suggested that the virus began to spread in Brazil even before this official case. 7,8

From the first case registered in the country, the new coronavirus began to spread to other regions in Brazil, and in the Northeast Region, the first case confirmed for COVID-19 occurred on March 6, 2020 in the State of Bahia.It was a 34-year-old woman who had traveled to Italy. 9,10

With its high transmissibility, SARS-CoV2 quickly spread around the world, and a pandemic was declared on March 11, 2020, so that by that day there were more than 118,000 cases of the disease distributed in 114 countries with a total of 4,291 deaths worldwide. 5,6

On March 20, 2020, the Ministry of Health recognized the community transmission of coronavirus in Brazil, putting the country in a state of alert to adopt preventive measures. ${ }^{11,12}$

Understanding how COVID-19 spread in the cities of Pernambuco State, this would allow us to hypothesize what may have influenced the acceleration in certain regions. The pandemic is strongly influenced by social and economic inequalities, which increases the challenge to prevent and control COVID-19. Therefore, coping strategies need intersectoral actions, taking into account the different contexts in the cities. This article sought to analyze how the dissemination of COVID-19 took place in the cities, Macro-regions and Health Regions in the State of Pernambuco, Northeast of Brazil.

\section{Methods}

A descriptive, exploratory study of a quantitative nature whose analysis units were the 184 cities and the Archipelago of Fernando de Noronha (State District) which constituents the state of Pernambuco. Pernambuco is located in the center-east of the Northeast region, with a total area of $98,067.881$ $\mathrm{km}^{2}$. It is the seventh most populous state in Brazil and the second in the Northeast, with an estimated population of $9,616,621.13$

The State of Pernambuco is organized into 4 macro-regions and 12 health regions. Macro-region 1 (Metropolitan), comprised of Health Regions I, II, III and XII; Macro-region 2 (Harsh area-Agreste), IV and V; Macro-region 3 (Hinterland-Sertão), VI, X and XI; and Macro-region 4 (San Francisco Valley), VII, VIII and IX.14

To understand how COVID-19 was disseminated in Pernambuco State, the date of the first case confirmed in each city was used as a variable. When available, information on sex and age of the first case was also collected.

The main source of data collection were the epidemiological bulletins made available by the city governments and health departments on their social networks (Facebook and Instagram) and official websites, as well as news sites and blogs and specific pages for the dissemination of COVID-19. The dissemination of COVID-19 in the cities in Pernambuco State was presented fortnight, considering the first 15 days of the month as the first fortnight and the other days of the month as the second fortnight.

The data were distributed in Excel tables, from the first confirmed case. Geoprocessing techniques were performed from the QGis 3.14.16 tool, as it is a software that allows to analyses, manipulate and generate data, presenting them in figures, which show how the propagation of COVID-19 occurred in the cities, Macro-regions and Health Regions.

\section{Results}

Of the 185 cities, considering the State District, Archipelago of Fernando de Noronha, 117 of them $(63 \%)$ informed the patient's sex in the first notifications of cases. Of these, in 67 cities $(57.3 \%)$ were male; in 44 cities $(37.6 \%)$ were female; and in 6 cities $(5.1 \%)$, simultaneous notification of both sexes occurred.The incompleteness of information was greater when it concerned the patients'age. Of the 185 units of analysis, only 88 cities informed the patient'sage, which represented $47.6 \%$ of the cities 
studied. In 88 cities, the patients'average age was 51.9 years after presenting the first cases. Regarding to the situation of the first case, 28 cities notified their first cases in patients who had died.

The confirmation of the first cases of COVID-19 in Pernambuco State, was in its capital, Recife, on March 12, 2020, two patients, a 71 year oldman and a 66 years old woman, both with recent history of traveling to Italy, while they had returned to Recife presented some symptoms suggestive of the disease and sought a private health service, and the results of the tests confirmed the detection of COVID-19. Four days after the arrival of COVID-19 in Pernambuco State, the first case was confirmed in the countryside of Pernambuco, in Belo Jardim, a $177.6 \mathrm{~km}$ distance from the capital, a 57-year-old man with a recent record of traveling to Italy with his family. Also in March 2020, 12 other cities confirmed their first cases of COVID-19. Pernambuco State ended the month of March with COVID-19 cases in 7\% of the cities (Figure 1).

Figure 2 shows the rapid interiorization of COVID-19 in Pernambuco State indicating that the peak of dissemination of the new coronavirus occurred in April 2020, 120 new cities confirmed the first case of the disease. In the first half of April, 51 cities, and in the second half of April, another 69 cities. In March (13 cities) and April (120 cities), Pernambuco had 133 (71.9\%) cities with confirmed cases of COVID-19 (Figure 2).

In May, 47 cities reported the confirmation of the disease: 33 cities in the first 15 days and 14 cities in the second half of May. By May 31, 2020, the state of Pernambuco already had cases of COVID-19 in $180(97.3 \%)$ cities, considering the Archipelago of Fernando de Noronha (Figure 3).

Figure 4 shows how the pandemic arrived in the last 5 cities in Pernambuco, which still had no confirmed cases of COVID-19. On June 1 and 6, the cities Calumbi and Exu confirmed the first case, on the $18^{\text {th }}$ and the $28^{\text {th }}$, Solidão and Mirandiba also reported the first case of COVID-19. From March 12 to June 30, 2020, Pernambuco State already had 184 (98.9\%) cities (considering the Archipelago of Fernando de Noronha) with COVID-19 cases, only one city did not confirmed any case of the disease.

On July 19, 2020, 129 days after the first case of COVID-19 in Pernambuco Sate, the first case was confirmed in Manari, a city located in the hinterland of Pernambuco, $350.5 \mathrm{~km}$ from the capital, the patient was a five-year-old child who when diagnosed in Recife was sent back to his residence in Manaria in order to maintain a home isolation. With this, the COVID-19 pandemic reached the entire state of Pernambuco (Figure 4).

Macro-region 2 was the first to have all its cities withcases of COVID-19 in 68 days, followed by Macro-region 1, with 76 days. Macro-region 3 was the last to register cases in all its cities, 102 days (Table 1).

When we take into consideration the dissemination of COVID-19 in all the cities from the Gerencia Regional de Saúde (GERES) (Regional Health Management), GERES $V$ was the first to register COVID-19 in all its 21 cities in 31 days, followed by GERES I (33 days), II (36 days), VIII (38 days) and XII (40 days). The GERES that most extended the arrival of COVID-19 in its cities was VI (102 days) (Table 1).

\section{Discussion}

As of December 2019, there was an emergence of COVID-19.1-4 In January 2020, the Public Health Emergency of International Concernhad already known. Even so, Brazil was not prepared for the arrival of the COVID-19 cases: the carnival festivities did not stop to take place, and there was no control atthe airports on the arrival of tourists, which may have contributed to accelerate the spread of the virus, since the first cases of COVID-19 in Brazil occurred in patients with international traveling records and in cities with high flow of tourists at carnival. $7,8,11,12$

Analyzing the dissemination process of COVID19 in Pernambuco, as it could be seen that in the month of April, it was decisive for the internalization process of the disease in the State. In that month, 120 of the 185 cities registered their first cases of COVID-19.

The rapid spread suggested an introduction of delayed detection and coping strategies or both. 15 The reality of Pernambuco State was not very different from other Brazilian States, 1,16 since it did not have sufficient infrastructure, especially at the beginning of the pandemic, enabling a large-scale of testing. The deficiency and decision-making of the surveillance systems in tracking the infected people, suggested that the virus was already present in the cities of Pernambuco before the official confirmation of the first case.

The State capital was the first city to register a case of COVID-19, only six days after the first case was confirmed in Brazil. This fact was already expected due to the economic and social flow and especially the existence of a port and an international airport in the city of Recife. Not by chance, the first two patients diagnosed with COVID-19 in the State 


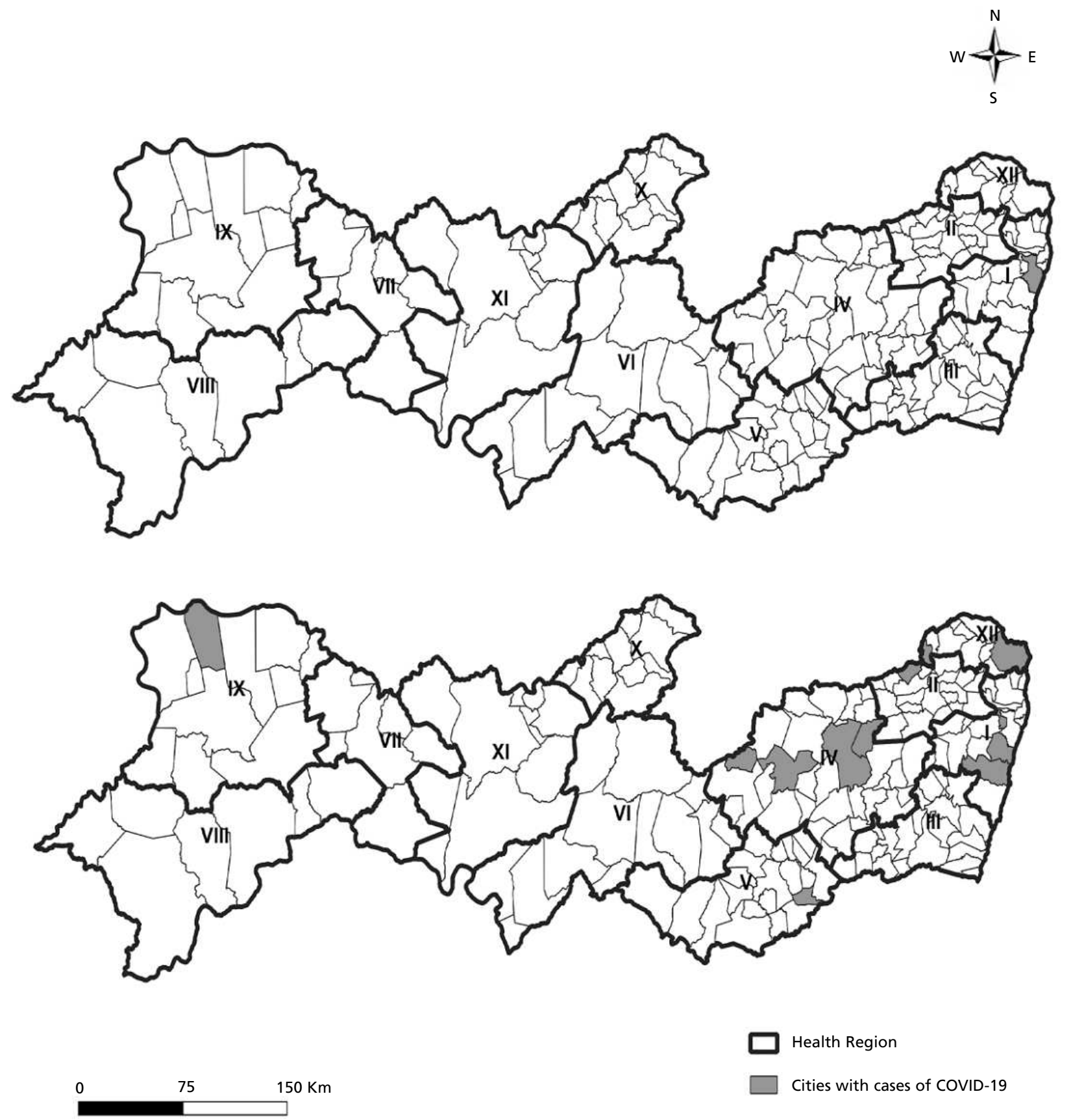




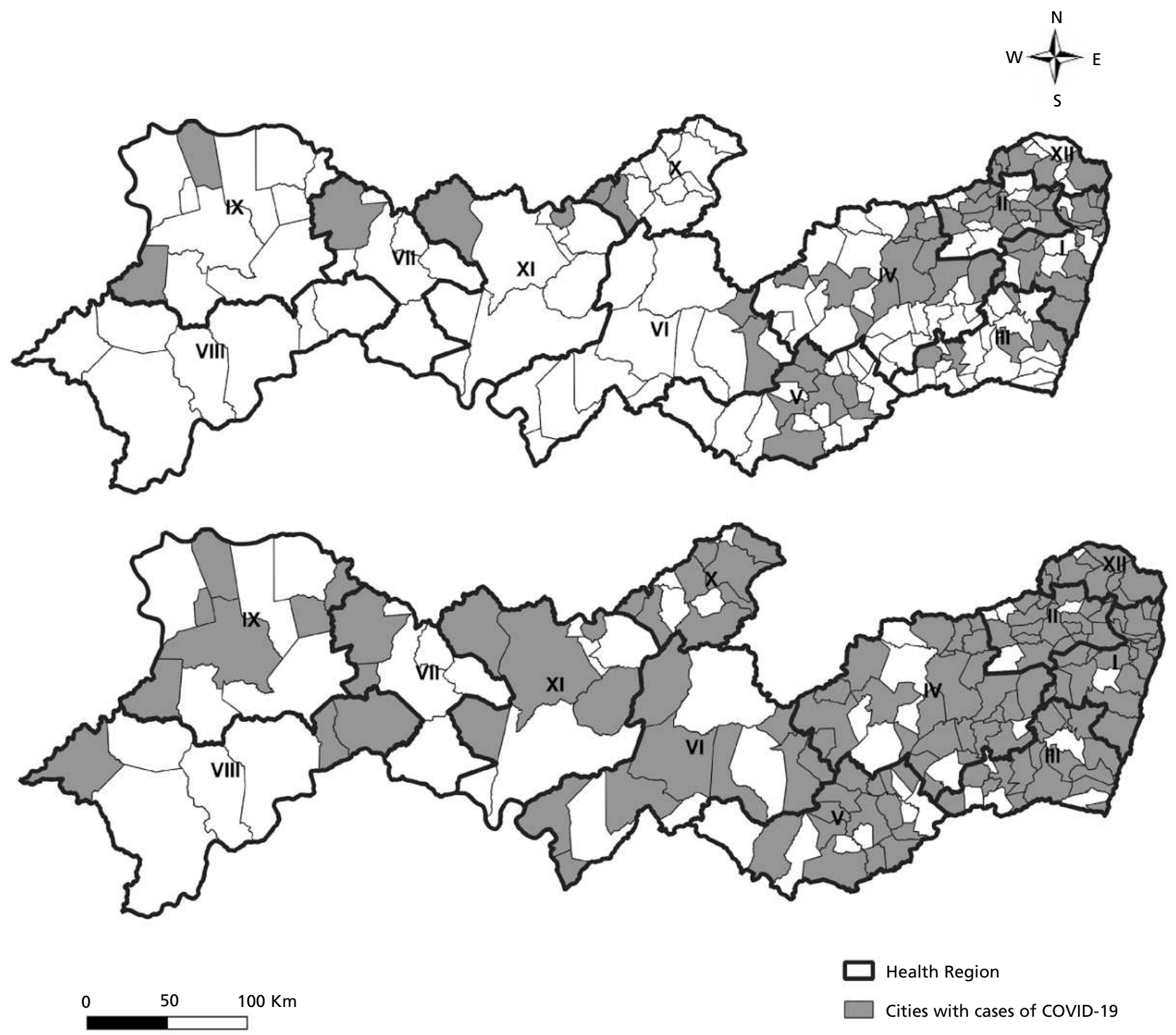



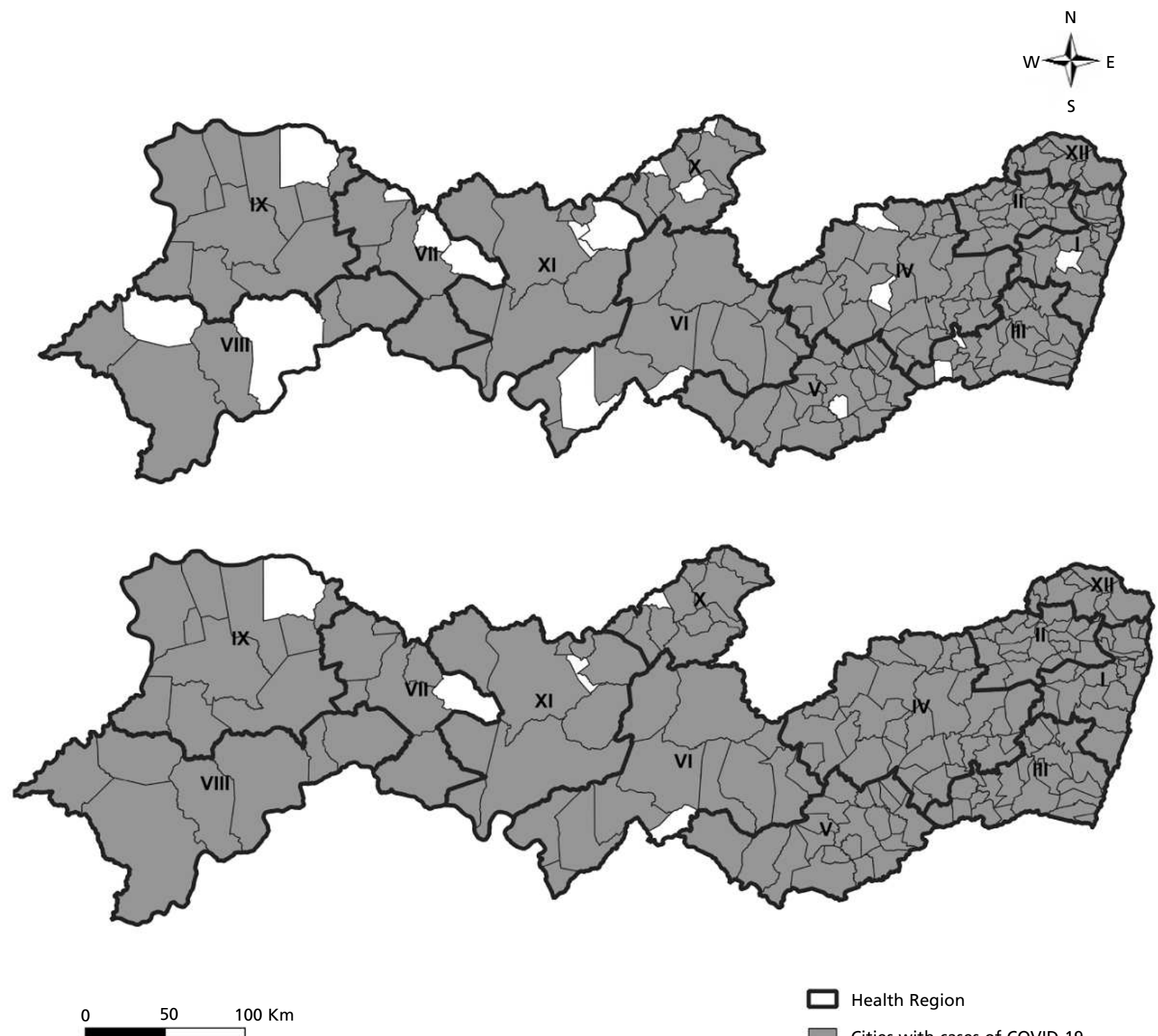

$\square$ Health Region

$\square$ Cities with cases of COVID-19 


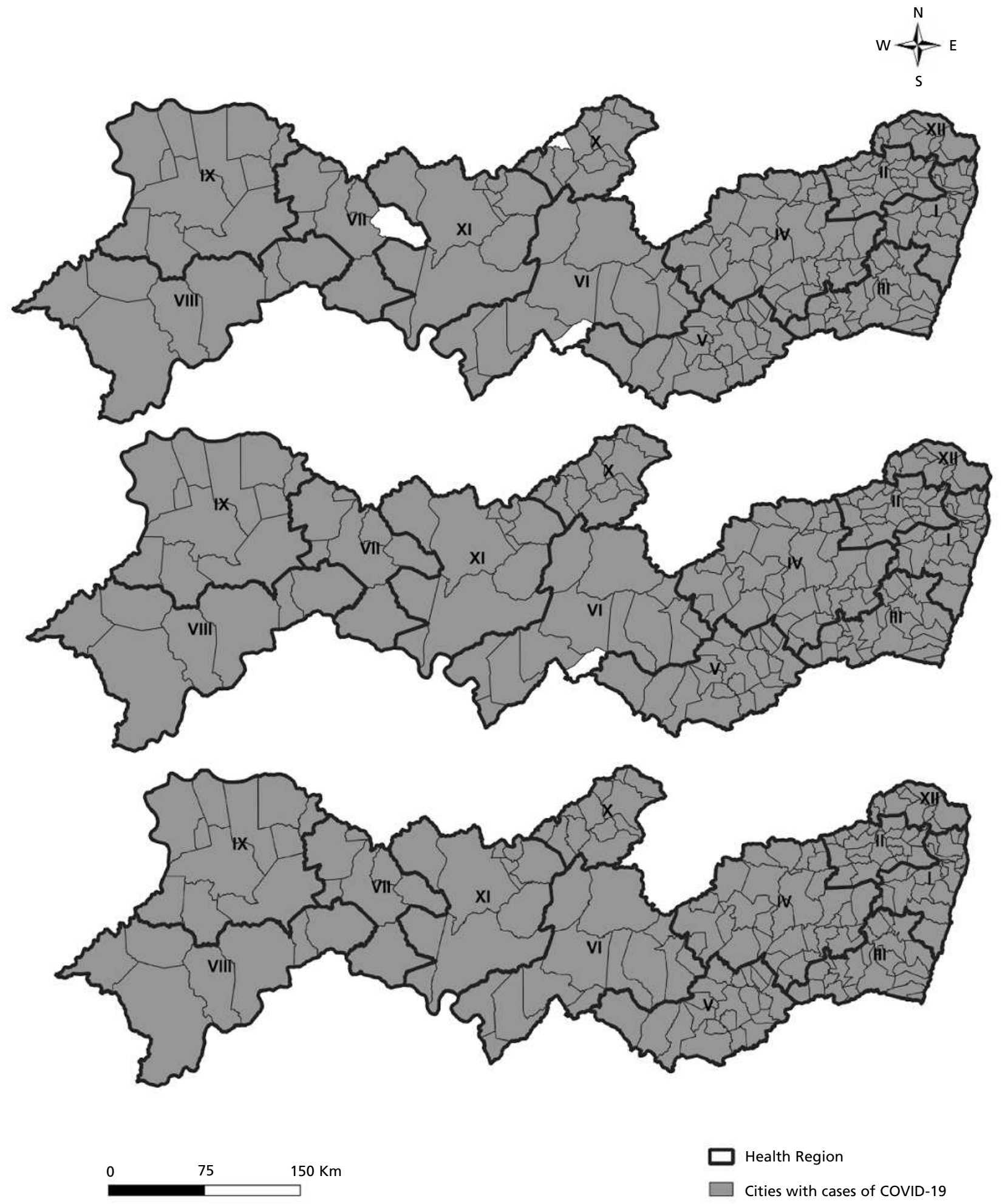


Table 1

\begin{tabular}{|c|c|c|c|c|c|c|}
\hline Macro & GERES & $\begin{array}{c}\text { Nuber of } \\
\text { cities }\end{array}$ & $\begin{array}{l}\text { Day and the } \\
\text { first city of } \\
\text { GERES with } \\
\text { COVID-19 }\end{array}$ & $\begin{array}{l}\text { Day and the } \\
\text { last city of } \\
\text { GERES with } \\
\text { COVID-19 }\end{array}$ & $\begin{array}{l}\text { Time, in days } \\
\text { - COVID-19 in } \\
\text { all the cities } \\
\text { of GERES }\end{array}$ & $\begin{array}{l}\text { Time, in days } \\
\text { - CovID-19 in } \\
\text { all the Macro } \\
\text { cities }\end{array}$ \\
\hline \multirow[t]{4}{*}{1} & I & $20 *$ & March 12 (Recife) & $\begin{array}{l}\text { April } 14 \text { (Ilha de } \\
\text { Itamaracá) }\end{array}$ & 33 & \\
\hline & II & 20 & April 6 (Paudalho) & $\begin{array}{l}\text { May } 12 \text { (Casinhas and } \\
\text { Vertente do Lério) }\end{array}$ & 36 & \\
\hline & III & 22 & March 30 (Palmares) & $\begin{array}{c}\text { May } 27 \text { (Belém de } \\
\text { Maria) }\end{array}$ & 58 & 76 \\
\hline & XII & 10 & March 27 (Goiana) & May 6 (Camutanga) & 40 & \\
\hline \multirow[t]{2}{*}{2} & IV & 32 & March 16 (Belo Jardim) & May 23 (Tacaimbó) & 68 & 68 \\
\hline & $\mathrm{V}$ & 21 & $\begin{array}{c}\text { April } 9 \text { (Garanhuns and } \\
\text { Capoeiras) }\end{array}$ & May 10 (Brejão) & 31 & \\
\hline \multirow[t]{3}{*}{3} & VI & 13 & April 8 (Arcoverde) & July 19 (Manari) & 102 & \\
\hline & $x$ & 12 & April 14 (Carnaíba) & June 18 (Solidão) & 65 & 102 \\
\hline & $\mathrm{XI}$ & 10 & April 9 (Serra Talhada) & June 1 (Calumbi) & 53 & \\
\hline \multirow[t]{3}{*}{4} & VII & 7 & April 6 (Salgueiro) & June 28 (Mirandiba) & 83 & \\
\hline & VIII & 7 & March 23 (Petrolina) & April 30 (Afrânio) & 38 & 97 \\
\hline & IX & 11 & March 30 (Ipubi) & June 6 (Exu) & 68 & \\
\hline
\end{tabular}

* Considering the Archipelago of Fernando de Noronha. 
had a recent history of travel to Italy. The cases with travel links represented almost two thirds of the first reported cases of COVID-19 in affected countries. 15

Each region of Pernambuco State has distinct social and economic particularities that need to be taken into account to reduce the impact of the virus, avoiding overburdening the health system and protecting people at higher risk of serious outcomes while waiting for an effective vaccine and treatment. 17 The accelerated growth of cases in the cities of the countryside, especially in the small ones, increased the concern about the adequate and installed structural conditions and to treat cases that needed hospitalization, especially in the regions of Harsh areas (Agreste) and the hinterlands.

Of the first five GERES that had confirmed cases of COVID-19 in all their cities, three are part of the Macro-region 1 (GERES I, II and XII). However, it was not Macro-region I that had the shortest interval of days between the first and the last city to register a case of COVID-19 (76 days).

Macro-region 2 was the first in chronological terms to have all its cities with cases of COVID-19, with an interval of 68 days. This fact signals a greater unpreparedness of Macro-region 2 in strategies to combat the coronavirus and the need for early recognition of suspicious cases, control practices and surveillance of health professionals to detect diseases. 15 GERES V should be especially highlighted, which in an interval of 31 days had all its 21 cities with cases of COVID-19.

In comparison, Macro-regions 3 (35) and 4 (25) have fewer cities than Macro-regions 1 (72) and 2 (53), and yet were the last to confirm COVID-19 cases in all the cities in an interval of 102 days and 97 days, respectively. The difference in time between macro-regions may have occurred due to the adoption of different strategies to combat the coronavirus, or even because Macro-regions 3 and 4 are geographically located further inland in the State. 34 days after the arrival of the pandemic in Pernambuco, most of the cities with new cases were located around BR 232, the main highway that leads towards the Harsh area (Agreste) and and the Hinterlands in Pernambucano. Until the first half of April, the presence of cases in the cities like Bezerros, Caruaru, Garanhuns, Belo Jardim, Arcoverde, Salgueiro and Petrolina indicated that the route of the new coronavirus through the countryside of Pernambuco followed an economic and social logistics.

This logic is reinforced by relating the Gross Domestic Product (GDP) of the cities in Pernambuco in 2017 and the dissemination of COVID-19, since the GDP is an important indicator of economic flow and the ability to attract labor and capital of a territory.

In Pernambuco, of the 20 largest GDPs of the cities, 14 are cities located in the health regions inserted in Macro-region I. 17 Then, of the 20 largest GDPs cities, 4 are cities located in health regions inserted in Macro-region II. The other 2 cities that are among the 20 highest GDP in the State are Petrolina and Serra Talhada which are, respectively, in Macro-region 4 and Macro-region 3. On the other hand, among the 20 lowest GDP in the State, 10 are cities in Macro-region 3, and 4 are from Macroregion $4 .{ }^{18}$

Thus, it can be seen that the higher the GDP of the city, the faster the arrival of the pandemic. The transmission settings of the first cases of COVID-19 can provide indications on the potential transmission factors of the community. 15

Metropolitan areas are a significant predictor of infection rates, since the connectivity, through economic and social relations, that exists in these regions, is more important than the population density in the spread of the SARS-CoV-2.19 Of the 20 largest estimated populations in Pernambuco State in 2019,20 17 are in cities located in the health regions of Macro-region 1 (13) and 2 (4).

The pandemic ended up putting pressure on the health systems in areas outside the capital and the main cities in the countryside, 21 as in Pernambuco which, due to the lack of structure for severe cases in the countryside, mainly at the beginning of the pandemic, generated lines for the Intensive Care Units. Managers needed to support the facilities in interpreting guidelines during a pandemic to mitigate its impact on their workforce. 22

Several factors may have contributed to the early prevalence of adults among confirmed cases, including early transmission associated with travel and occupational exposure. ${ }^{15}$ The viral transition time may have contributed to the rapid spread of the virus, as there are no scientific recommendations for returning to occupational activities after 14 days, a time considered insufficient for many patients, who are still eliminating the virus in respiratory secretions. 16,23

It is necessary to consider that the late isolation and noncompulsory wearing of masks, presented in the State decree, 65 days after the first case of COVID-19 in Pernambuco. ${ }^{24}$ Combined isolation and screening strategies would reduce the transmission more than mass testing or self-isolation alone. 25 In addition, the combination of RT-PCR and serology should also be implemented for case 
tracking and contact screening to facilitate early diagnosis, immediate isolation and treatment. ${ }^{26}$

It can be seen that the COVID-19 pandemic has highlighted disparities between social classes, since the idea of social isolation for individuals living in agglomerated environments is somehow a utopia. 27 In Pernambuco, of the 17 cities with subnormal urban agglomerations, ${ }^{28} 14$ are GERES I, 1 in GERES III and 2 in GERES IV, which are part of Macro-regions 1 and 2, first with cases of COVID19 in all the cities.

To ensure the cessation of an epidemic, rapid identification of cases, quarantine measures and physical distancing were needed to prevent secondary transmission. ${ }^{29}$ The consensus is that rigorous mitigation measures are needed at the outset to slow transmission of SARS-CoV-2, and such measures may possibly interrupt the pandemic if individuals follow the specific guidelines of thecountry. 17

In the case of COVID-19, confirmation of the spread was detected from reported cases, but due to the scarcity of testing, especially at the beginning of the pandemic, this reality could possibly have been anticipated.

The rapid dissemination of COVID-19 in all the cities in Pernambuco in 129 days showed the need for improvement in the Health Surveillance strategies and for signaling the inability of the Health Surveillance in controlling the transmission, especially in small towns, the way the pandemic spread and by identifying the first Health Macro-regions and Regions that had all their cities affected by COVID-19.

The epidemiology of a pandemic respiratory virus changes rapidly and responses must be agile. Other pandemics have shown us how much accurate and timely local information is needed to enable and guide the interventions that could have had a greater impact if they had been adopted earlier and more widely, with rapid action requiring community confidence and accession. 30

During the research, several challenges were encountered due to the failures of the Health Surveillance, such as the search for information regarding the first case, since some cities published COVID-19 reports only through Facebook or the city hall Instagram, specific websites, or just citation of the first case without making use of epidemiological bulletins or any standardization for communication, information and updating of the epidemiological situation of the pandemic.

The difficulty in obtaining information for this study in the face of a pandemic, highlights how necessary it is to advance communication strategies with the population in order to make information available quickly and safely. This is even more relevant in a context of health emergency. Given the complex risks and perceptions associated with a pandemic, communication strategies that simply disseminate information and recommendations about outbreaks will be insufficient.

Besides the difficulties in finding information from the first case, the incompleteness of the information disseminated in epidemiological newsletters and notes on websites, regarding the first case, ended up limiting this study to work with fewer variables.

As the data used are in the public domain, without the possibility of exposing the patients, the need for future studies with access to the primary information of these patients is pointed out, in order to understand the clinical manifestations and the socioeconomic characteristics.

It is essential to carry out an analysis of the capacity of the cities to treat cases before and after the arrival of a pandemic, as well as the creation of adequate plans to confront the disease that can serve as future experiences.

It is expected that this study may contribute in several aspects, among them the need for redirecting resources to areas in more need, strengthening the Health Surveillance strategies, from continuous training that may be reflected in the improvement of strategies for disease promotion, prevention and control.

\section{Authors' contribution}

Silva RR coordinated the research and the planning of the study. Participated in data collection, manuscript writing, analysis and discussion of the results, version review and critical review of content. Guilhermino GMS participated in the planning of the study. Participated in data collection, manuscript writing, analysis and discussion of the results, version review and critical review of content. Oliveira BL participated in data collection, analysis and discussion of the results, version review. Lira Neto JB participated in data collection. All authors approved the final version of the article. 


\section{References}

1. Freire-Silva J, Ferreira HS, Candeias ALB, Pinho MAB, Oliveira BRB. A utilização do planejamento territorial no combate da COVID-19: considerações sobre a situação dos leitos nos municípios de Pernambuco, Brasil. Visa em Debate 2020; 8 (2): 16-27.

2. WHO (World Health Organization). Report of the WHOChina Joint Mission on Coronavirus Disease 2019 (COVID-19). Genebra; 2020.

3. Zhu N, Zhang D, Wang W, Li X, Yang B, Song J, Zhao X, Huang B, Shi W, Lu R, Niu P, Zhan F, Ma X, Wang D, Xu W, Wu G, Gao GF, Tan W. A novel coronavirus from patients with pneumonia in China, 2019. N Engl J Med $2020 ; 382$ (8): 727-33.

4. Mizumoto K, Kagaya K, Chowell G. Effect of a wet market on coronavirus disease (COVID-19) transmission dynamics in China, 2019-2020. Int J Infect Dis 2020; 97: 96-101.

5. WHO (World Health Organization). Timeline of WHO's response to COVID-19. Genebra; 2020.

6. WHO (World Health Organization).WHO DirectorGeneral's opening remarks at the media briefing on COVID-19. Genebra; 2020.

7. Burki T. COVID-19 in Latin America. Lancet Infect Dis 2020; 20 (5): 547-8

8. Brasil. Ministério da Saúde. Brasil confirma primeiro caso da doença. 2020 [acesso 24 ago 2020]. Disponível em: https://www.saude.gov.br/noticias/agencia-saude/46435brasil-confirma-primeiro-caso-de-novo-coronavirus

9. Delatorre E, Mir D, Gräf T, Bello G. Tracking the onset date of the community spread of SARSCoV-2 in Western Countries. Mem Inst Oswaldo Cruz. 2020; 115: 1-7.

10. Brasil. Ministério da Saúde declara transmissão comunitária nacional. 2020 [acesso 24 ago 2020]. Disponível em: https://www.saude.gov.br/noticias/agencia-saude/46568ministerio-da-saude-declara-transmissao-comunitarianacional

11. Marinelli NP, Albuquerque LPA, Sousa IDB, Batista FMA, Mascarenhas MDM, Rodrigues MTP. Evolução de indicadores e capacidade de atendimento no início da epidemia de COVID-19 no Nordeste do Brasil, 2020. Epidemiol Serv Saúde. 2020; 29 (3): 1-10.

12. Bahia. Secretaria de Saúde do Estado da Bahia. Bahia confirma primeiro caso importado do Novo Coronavírus (Covid-19). 2020 [acesso 24 ago 2020]. Disponível em: http://www.saude.ba.gov.br/2020/03/06/bahia-confirmaprimeiro-caso-importado-do-novo-coronavirus-covid-19/

13. Instituto Brasileiro de Geografia e Estatística. Cidades e Estados: Pernambuco. 2020 [acesso 9 nov 2020] Disponível em: https://www.ibge.gov.br/cidades-e-estados/pe.htm

14. Pernambuco. Secretaria de Saúde do Estado de Pernambuco. Plano Diretor de Regionalização. 2011. [acesso 24 ago 2020]. Disponível em: http://portal.saude.pe.gov.br/sites/portal.saude.pe.gov.br/fil es/pdrconassversao_final1.doc_ao_conass_em jan_2012.pdf

15. Dawood FS, Ricks P, Njie GJ; Daugherty M, Davis W, A Fuller J, Winstead A, McCarron M, Scott LC, Chen D, Blain AE, Moolenaar R, Li C, Popoola A, Jones C,
Anantharam P, Olson N, Marston BJ, Bennett SD Observations of the global epidemiology of COVID-19 from the prepandemic period using web-based surveillance: a cross-sectional analysis. Lancet Infect Dis. 2020; 1:9.

16. Magalhães JJF, Mendes RPG, Silva CTA, Silva SJR, Guarines KM, Pena L. Epidemiological and clinical characteristics of the first 557 successive patients with COVID-19 in Pernambuco state, Northeast Brazil. Travel Med Infect Dis. 2020; 38: 101884.

17. Petersen E, Koopmans M, GO U, Hamer DH, Petrosillo N, Castelli F, Storgaard M, Khalili SA, Simonsen L. Comparing SARS-CoV-2 with SARS-CoV and influenza pandemics. Lancet InfectDis. 2020; 20 (9): 238-44.

18. IBGE (Instituto Brasileiro de Geografia e Estatística). Produto Interno Bruto dos Municípios. 2019b. [acesso 24 set 2020]. Disponível em: https://ibge.gov.br/estatisticas/ economicas/contas-nacionais/9088-produto-interno-brutodos-municipios-html?-\&t=o-que-e

19. Hamidi S, Sabouri S, Ewing R. Does Density Aggravate the COVID-19 Pandemic? J Am Plann Assoc. 2020; 86 (4): 495-509.

20. IBGE (Instituto Brasileiro de Geografia e Estatística). Estimativas da População. 2019a. [acesso 24 set 2020]. Disponível em: https://ibge.gov.br/estatisticas/sociais/populacao/9103-estimativas-de-populacao.html?-\&t=o-que-e

21. Daniels JP. COVID-19 cases surge in Colombia. Lancet 2020; 396 (10246): 227.

22. Bielicki J, Duval X, Gobat N, Goossens H, Koopmans M, Tacconelli E, Werf S. Monitoring approaches for healthcare workers during the COVID-19 pandemic. Lancet Infect Dis. 2020; 20 (10): 261-267.

23. Zhou F, Yu T, Du R, Fan G, Liu Y, Liu Z, JieX, Yeming W, Bin S, Xiaoying G, Lulu G, Yuan W, Hui L, Xudong, W, Jiuyang X, Shengjin T, Yi Z, Hua C, Bin C. Clinical course and risk factors for mortality of adult inpatients with COVID-19 in Wuhan, China: a retrospective cohort study. Lancet 2020; 395(10229): 1054-1062.

24. Pernambuco. Decreto $\mathrm{n}^{\circ} 49.017,11$ de maio de 2020. Dispõe sobre intensificação de medidas restritivas, de caráter excepcional e temporário, voltadas à contenção da curva de disseminação da Covid-19. [acesso 24 set 2020]. Disponível em: https://www.pecontracoronavirus.pe.gov.br/ wp-content/uploads/2020/05/no-49-017.pdf

25. Kucharski AJ, Klepac P, Conlan AJK, Kissler SM, Tang ML, Fry H, GogJR, Edmunds WJ. Effectiveness of isolation, testing, contact tracing, and physical distancing on reducing transmission of SARS-CoV-2 in different settings: a mathematical modelling study. Lancet Infect Dis. 2020; 20 (10): 1151-1160.

26. Hung IF, Cheng VC, Li X, Tam AR, Hung DL, Chiu KH, Yip CC, Cai J, Ho DT, Wong S, Leung SS, Chu M, Tang MO, Chen JH, Poon RW, Fung AY, Zhang RR, Yan EY, Chen L, Choi CY, Leung K, Chung TW, Lamn SH, Lam TP, Chan JF, Chan K, Wu T, Ho P, Chan JW, Lau C, To KK, Yuen K. SARS-CoV-2 shedding and seroconversion among passengers quarantined after disembarking a cruise ship: a case series.Lancet InfectDis. 2020; 20 (9): 1051-60. 
27. Buheji M, Cunha KC, Beka G, Mavrić B, Souza YLC, Silva SSC, Hanafi M, Yein TC. The Extent of COVID-19 Pandemic Socio-Economic Impact on Global Poverty. A Global Integrative Multidisciplinary Review. Am J Econ Sociol. 2020; 10 (4): 213-24.

28. IBGE (Instituto Brasileiro de Geografia e Estatística). Censo Demográfico 2010: Aglomerados Subnormais 2010b. [acesso 24 set 2020]. Disponível em: https://biblioteca.ibge.gov.br/visualizacao/periodicos/92/cd 2010_aglomerados_subnormais.pdf
29. Venkatesan P. COVID-19 in Iran: round 2. Lancet Infect Dis. $2020 ; 20$ (7): 784.

30. Celum C, Barnabas R, Cohen MS, Collier A, El-Sadr W, Holmes KK, Johnston C, Piot P. Covid-19, Ebola, and HIV - Leveraging Lessons to Maximize Impact. N Engl J Med. 2020; 383 (19): e106.

Received on October 13, 2020

Approved on November 3, 2020 